
\title{
R Resercrch Suare \\ Effects of Wetland Plant Biochars on Heavy Metal Immobilization and Enzyme Activity in Soils From the Yellow River Estuary
}

\section{Lidi Zheng}

Fujian Normal University Cangshan Campus: Fujian Normal University

Chuan Tong

Fujian Normal University Cangshan Campus: Fujian Normal University

Jujuan Gao

fujian minjiang river estuary wetland national nature reserve adminitrative office

Rong Xiao (D xiaorong_526@163.com )

Fuzhou University

\section{Research Article}

Keywords: Biochar, Wetland soil, Heavy metal, Enzyme activity

Posted Date: July 12th, 2021

DOI: https://doi.org/10.21203/rs.3.rs-626669/v1

License: (c) (i) This work is licensed under a Creative Commons Attribution 4.0 International License.

Read Full License 


\section{Abstract}

Estuarine wetlands provide a variety of ecosystem services, including carbon sinks, nitrogen removal, marine habitats, and climate regulation. However, many estuarine marshes are suffering from soil heavy metal pollution, which significantly affects soil enzyme activities that influence the carbon and nitrogen biogeochemical cycles in wetlands. To date, studies on the effects of wetland plant biochars on heavy metal adsorption and enzyme activity in estuarine wetland soil are limited. The purpose of this study was to assess the effects of wetland plant biochars on the enzyme activity in heavy metal contaminated soil. The biochars were produced from Phragmites australis (PB), Suaeda salsa (SB), and Tamarix chinensis (TB) under different pyrolysis temperatures and times. The detected pyrolysis products showed that the ash, $\mathrm{pH}$, electrical conductivity, and carbon content of the biochars increased significantly, while the production rate of the biochars decreased with increasing pyrolysis temperature and time. The results of the adsorption experiments indicated that biochar addition could effectively reduce the concentration of $\mathrm{Pb}$ and/or $\mathrm{Cd}$ in the $\mathrm{Pb}^{2+} / \mathrm{Cd}^{2+}$ single or mixed solutions, but the $\mathrm{Pb}^{2+}$ and $\mathrm{Cd}^{2+}$ in the mixed solution indicated a competitive adsorption. A 30-day incubation experiment was conducted using salt marsh soil amended with different biochar application rates to investigate the short-term effects of biochar addition on $\mathrm{Pb}$ and $\mathrm{Cd}$ immobilization. The PB and SB significantly immobilized $\mathrm{Pb}$ within the first 15 days, but $\mathrm{Pb}$ remobilized within the next 15-day period. In contrast, TB addition did not significantly fix Pb. Moreover, biochar addition promoted the conversion of $\mathrm{Cd}$ from the residue to the less immobile fractions. The addition of three types of plant biochar had no significant effect on the urease activity in wetland soil but significantly increased soil sucrase activity. PB and SB significantly promoted catalase activity, while TB significantly inhibited soil catalase activity.

\section{Introduction}

Heavy metal pollution in soil adversely affects ecosystem health and food safety. Many coastal/estuarine wetland soils are highly contaminated with heavy metals (Zhang et al., 2016; Cheng et al., 2017). The Yellow River Estuary is the largest and youngest estuarine wetland ecosystem in China. In recent years, rapid industrialization, urbanization, and growth of agricultural practices in the coastal zones of the Yellow River Estuary has increased the risks of heavy metal pollution in wetland water and soil (Zheng et al., 2017). For example, the content of $\mathrm{Pb}$ and $\mathrm{Cd}$ in the wetland soil of the Yellow River Delta was found to be significantly higher than that of the local soil, which is a major concern due to their high mobility and persistence in the environment (Yao et al., 2016). Therefore, reasonable and feasible measures need to be theoretically developed, considering developmental changes in wetland water quality and soil environmental safety.

Biochar is the product of biomass pyrolysis under high temperature and low or no oxygen conditions. Compared with the traditional lime, phosphate, and other modifiers, the surface of biochar is rich in functional groups, negatively charged, and has high cation exchange capacity, porosity, and specific surface area (Schimmelpfennig and Glaser, 2012; Zhang et al., 2013). In recent years, the benefits associated with biochar soil application (beyond its strong adsorption and immobilization capacity of 
heavy metals) have been reported increasingly (Sohi et al., 2010; Tong et al., 2011; Rinklebe et al., 2016). The physico-chemical properties of biochar are affected by biomass type and preparation conditions (pyrolysis temperature, carbonization time, etc.), which directly affects the remediation success of the heavy metal contaminated soil (Bian et al., 2014; Shen et al., 2016; Al-Wabel et al., 2017). Moreover, biochar production rates decrease, $\mathrm{pH}$ increases, and carbon percentage increases with increasing pyrolysis temperatures. However, higher pyrolysis temperature scarcely alters biochar aromaticity but decreases biochar polarity and increases the specific surface area (Xu and Zhao, 2013; Yuan et al., 2013). Higher biochar amounts will also affect heavy metal adsorption and immobilization efficiency.

Previous studies observed a gradual decrease in the bioavailability of heavy metals in soil with increasing biochar addition (Park et al., 2011; Houben et al., 2013; Xu and Zhao, 2013). For example, a rice straw biochar produced at $300^{\circ} \mathrm{C}$ had an adsorption capacity of $2.4 \mathrm{mg} \mathrm{g}^{-1}$ in a Pb solution (Liu and Zhang, 2009). A $2 \%$ addition of Eichhornia crassipes biochar significantly reduced the soil extractable $\mathrm{Pb}$ after 30 days of incubation (Yin et al., 2016). However, some studies have shown that biochar enhances the activity of certain heavy metals in the soil due to the supply of dissolved organic carbon from the biochar. For example, the addition of biochar and green manure to contaminated soils significantly increased the content of $\mathrm{Zn}$ and $\mathrm{Cu}$ in the soil pore water due to the significant increase in soil dissolved organic carbon and $\mathrm{pH}$ (Beesley et al., 2010). Previous studies assessing the adsorption and immobilization of heavy metals by biochar were mostly based on the remediation of heavy metal pollution in farmland and mining areas; however, few studies have assessed coastal/estuarine salt marshes and saline soils under potential risk of $\mathrm{Pb} / \mathrm{Cd}$ pollution, especially by adopting the native salt marsh plants as biochar resources.

Soil enzyme activity reflects the soil microbial processes. Many studies have assessed the effects of biochar addition on soil enzyme activities and microorganisms, most of which are related to the carbon and nitrogen cycle. Soil carbon, nitrogen, $\mathrm{pH}$, and cation exchange capacity have been shown to affect soil enzyme activity (Gianfreda and Rao, 2008; Paz-Ferreiro et al., 2012), and biochar can indirectly affect soil enzyme activity by affecting these indicators. Biochar also contains nutrients required for microorganism growth, such as phosphorus, potassium, and magnesium; these nutrients can enhance the soil enzyme activity (Lehmann et al., 2011) by promoting soil microbial activity. However, different biochar and soil types have different effects on soil enzymes. Imparato et al. (2016) found that high concentrations of wheat straw gasified biochar could promote soil phenoloxidase and reduce cellulase. Zhou et al. (2015) found that the addition of peanut shell biochar significantly increased the soil sucrase and urease activities, and the soil enzyme activity increased with increasing amounts of biochar. Biochar can also affect the activities of soil redox enzymes, such as dehydrogenase and catalase. For example, some studies found that adding different types of biochar to soil increased the soil dehydrogenase activity (Paz-Ferreiro et al., 2012; Sopeña and Bending, 2013). Feng et al. (2015) found that $0.5 \%$ addition of corn straw charcoal inhibited the activities of catalase and neutral phosphatase in brown soil. Zou et al (2015) found that biochar promoted the activities of sucrase and urease but inhibited the activity of neutral phosphatase in cucumber continuous cropping soil. Another study found that the soil sucrase 
and alkaline phosphatase activities were significantly inhibited when biochar concentrations reached 50 $\mathrm{mg} \mathrm{kg}^{-1}$, while the soil urease and alkaline phosphatase activities increased (Huang et al., 2017) under biochar concentrations of $10 \mathrm{mg} \mathrm{kg}^{-1}$.

In this study, we prepared biochar using three native wetland plants and studied the differences in the physical and chemical properties of biochar under different preparation conditions. Through the addition of biochar under experimental conditions, we aimed to assess the effects of the different biochars on the fixation of heavy metals and soil typical enzyme activity in the wetland soil of the Yellow River Delta. In practice, our study provides a guide for the application of wetland plant biochar to remediate soil heavy metal pollution in wetlands. Moreover, our findings also provide a scientific basis for the improvement and management of soil environment in similar estuarine wetlands.

\section{Material And Methods}

\subsection{Study sites and soil collection}

The experimental soil $(0-10 \mathrm{~cm})$ was collected from the Yellow River Delta Experimental Station $\left(37^{\circ} 45^{\prime} 46^{\prime \prime} \mathrm{N}, 118^{\circ} 58^{\prime} 53^{\prime \prime} \mathrm{E}\right)$ in October 2020 . The surrounding wetland plants were mainly Phragmites australis (PB), Suaeda salsa (SB), and Tamarix chinensis (TB), and these species were collected for experimental analyses. The aboveground parts of PB and SB were withered, while the leaves of TB were still green in appearance at the time of collection. The properties of the soil samples were as follows: moisture content: $30.17 \pm 1.21 \%$; $\mathrm{pH}: 8.13 \pm 0.21$; electrical conductivity (EC): $9.22 \pm 0.12 \mathrm{mS} \mathrm{cm}^{-1}$; soil organic carbon (SOC): $7.97 \pm 0.27 \mathrm{~g} \mathrm{~kg}^{-1}$; total nitrogen: $0.60 \pm 0.11 \mathrm{~g} \mathrm{~kg}^{-1}$; total phosphorus: $552 \pm 38$ $\mathrm{mg} \mathrm{kg}{ }^{-1} ; \mathrm{Pb}$ concentration: $17.13 \pm 2.03 \mathrm{mg} \mathrm{kg}^{-1}$; and Cd concentration: $0.23 \pm 0.09 \mathrm{mg} \mathrm{kg}^{-1}$. The soil was air-dried at room temperature and passed through a $2 \mathrm{~mm}$ sieve to remove the plant residues and impurities. Air-dried soil was homogenized before the physico-chemical property analyses and the incubation experiment (Zheng et al., 2017).

\subsection{Biochar production}

The experimental wetland plants were dried and dehydrated at $60^{\circ} \mathrm{C}$ and then crushed after reaching a constant weight. The dry stems and twigs were then smashed in a pulverizer and placed into a covered crucible for carbonization in a muffle furnace at 300,400 , or $500^{\circ} \mathrm{C}$ for 30,60 , and 120 minutes (Igalavithana et al., 2017). The prepared biochars from the three plants (PB, SB, TB) were stored in a desiccator, and a total of 27 types of biochars were produced (Table 1). The $\mathrm{pH}$ of the biochars was measured by adding the biochar to deionized water at a mass/water ratio of 1:20 (Cui et al., 2016). The EC was measured by a conductivity meter (VWR Scientific, West Chester, PA, USA), and the carbon levels were determined via dichromate oxidation (Wang et al., 2016). The acid functional group distribution was determined using the Boehm titration method (Mukherjee et al., 2011). 
Table 1

The 27 kinds of biochars produced from different sources.

\begin{tabular}{|c|c|c|c|}
\hline Biomass & $\begin{array}{l}\text { Pyrolysis Temperature, } \\
{ }^{\circ} \mathrm{C}\end{array}$ & $\begin{array}{l}\text { Pyrolysis Time, } \\
\text { minute }\end{array}$ & Abbreviations \\
\hline & & 30 & P300-1 \\
\hline & 300 & 60 & P300-2 \\
\hline & & 120 & P300-3 \\
\hline & & 30 & P400-1 \\
\hline \multirow[t]{9}{*}{ Phragmites australis } & 400 & 60 & P400-2 \\
\hline & & 120 & P400-3 \\
\hline & & 30 & P500-1 \\
\hline & 500 & 60 & P500-2 \\
\hline & & 120 & P500-3 \\
\hline & & 30 & S300-1 \\
\hline & 300 & 60 & S300-2 \\
\hline & & 120 & S300-3 \\
\hline & & 30 & $S 400-1$ \\
\hline \multirow[t]{9}{*}{ Suaeda salsa } & 400 & 60 & S400-2 \\
\hline & & 120 & S400-3 \\
\hline & & 30 & S500-1 \\
\hline & 500 & 60 & S500-2 \\
\hline & & 120 & S500-3 \\
\hline & & 30 & T300-1 \\
\hline & 300 & 60 & T300-2 \\
\hline & & 120 & T300-3 \\
\hline & & 30 & T400-1 \\
\hline \multirow[t]{4}{*}{ Tamarix chinensis } & 400 & 60 & T400-2 \\
\hline & & 120 & T400-3 \\
\hline & & 30 & T500-1 \\
\hline & 500 & 60 & T500-2 \\
\hline
\end{tabular}




\begin{tabular}{|llll|}
\hline Biomass & $\begin{array}{l}\text { Pyrolysis Temperature, } \\
{ }^{\circ} \mathrm{C}\end{array}$ & $\begin{array}{l}\text { Pyrolysis Time, } \\
\text { minute }\end{array}$ & Abbreviations \\
\hline & 120 & $\mathrm{~T} 500-3$ \\
\hline
\end{tabular}

\subsection{SEM and EDS spectra}

Scanning electron microscope (SEM) (Hitachi S-3400N-II) imaging was used to compare the structure and surface characteristics of biochar. A surface element analysis of biochar was conducted with the SEM using energy dispersive X-ray spectroscopy (EDS, Hitachi SU-8010).

\subsection{Laboratory incubation experiment}

Based on the soil $\mathrm{Pb}$ and $\mathrm{Cd}$ concentrations in the Yellow River Estuary, a solution with $\mathrm{Pb}^{2+}$ concentration of $200 \mathrm{mg} \mathrm{L}^{-1}$ using $\mathrm{Pb}\left(\mathrm{NO}_{3}\right)_{2}$, a solution with $\mathrm{Cd}^{2+}$ concentration of $5 \mathrm{mg} \mathrm{L}^{-1}$ using $\mathrm{Cd}\left(\mathrm{NO}_{3}\right)_{2}$, and a mixed solution of $\mathrm{Pb}^{2+}\left(200 \mathrm{mg} \mathrm{L}^{-1}\right)$ and $\mathrm{Cd}^{2+}\left(5 \mathrm{mg} \mathrm{L}^{-1}\right)$ with $0.01 \mathrm{~mol} \mathrm{~L}^{-1} \mathrm{Ca}\left(\mathrm{NO}_{3}\right)_{2}$ as an electrolyte (Celis et al., 2000) were perpared for the experiment. The biochar $(0.2 \mathrm{~g})$ was added into a centrifuge tube containing $50 \mathrm{ml} \mathrm{Pb}^{2+}$ and $\mathrm{Cd}^{2+}$ single or mixed ion solution. After shaking at room temperature $\left(25^{\circ} \mathrm{C}\right)$ for $2 \mathrm{~h}$, the final suspensions were centrifuged and filtered, and the supernatant solution was separated for the analysis of $\mathrm{Pb}$ and $\mathrm{Cd}$ concentrations via inductively coupled plasmaatomic emission spectrometry (ICP-AES) (Dai and Liu, 2013). Each treatment had three replicates.

According to the result of our adsorption experiment, the biochars produced under the pyrolysis condition of $500^{\circ} \mathrm{C}$ and $120 \mathrm{~min}$ had the highest $\mathrm{Pb}^{2+}$ and $\mathrm{Cd}^{2+}$ adsorption rates and were therefore selected as the biochar resource for the incubation experiment. More than $200 \mathrm{~g}$ of biochar produced from each of the three wetland plants was prepared for the soil incubation experiment. The biochars were uniformly mixed into the soils at rates of $0.5 \%, 1 \%$, and $2 \%$ (dry soil ratio, w/w), with the control group receiving no biochar (Table 2). Each treatment had three replicates. The amended soils were placed in $500 \mathrm{~mL}$ plastic bottles and incubated in a dark room at $25^{\circ} \mathrm{C}$ for 30 days. We added deionized water each day to maintain the moisture content ( $30 \%$ ), and the soils were sampled at 15 and 30 days. Heavy metal fractionations were determined by the Tessier continuous extraction method (Tessier et al., 1979). Moreover, the soil enzyme activities were detected after 30 days of cultivation. The urease activity was determined by sodium phenate and sodium hypochlorite colorimetry; sucrase activity were assayed via 3,5-dinitrosalicylic acid colorimetry (Hu et al., 2006); and catalase activity was detected via potassium permanganate titration (Edwards et al., 1992). 
Table 2

Treatments of incubation experiments.

\begin{tabular}{|c|c|}
\hline Description of treatments & Abbreviations \\
\hline 200 g soil (Control) & CK \\
\hline $200 \mathrm{~g}$ soil + $1 \mathrm{~g}$ biochar (P500-3) $(0.5 \% \mathrm{w} / \mathrm{w})$ & $\mathrm{P} 1$ \\
\hline $200 \mathrm{~g}$ soil $+2 \mathrm{~g}$ biochar (P500-3) $(1 \% \mathrm{w} / \mathrm{w})$ & P2 \\
\hline $200 \mathrm{~g}$ soil $+4 \mathrm{~g}$ biochar $(\mathrm{P} 500-3)(2 \% \mathrm{w} / \mathrm{w})$ & P3 \\
\hline $200 \mathrm{~g}$ soil + $1 \mathrm{~g}$ biochar $(\mathrm{S} 500-3)(0.5 \% \mathrm{w} / \mathrm{w})$ & S1 \\
\hline $200 \mathrm{~g}$ soil $+2 \mathrm{~g}$ biochar $(\mathrm{S} 500-3)(1 \% \mathrm{w} / \mathrm{w})$ & S2 \\
\hline $200 \mathrm{~g}$ soil $+4 \mathrm{~g}$ biochar $(\mathrm{S} 500-3)(2 \% \mathrm{w} / \mathrm{w})$ & S3 \\
\hline $200 \mathrm{~g}$ soil + $1 \mathrm{~g}$ biochar $(\mathrm{T} 500-3)(0.5 \% \mathrm{w} / \mathrm{w})$ & T1 \\
\hline $200 \mathrm{~g}$ soil + $2 \mathrm{~g}$ biochar $(\mathrm{T} 500-3)(1 \% \mathrm{w} / \mathrm{w})$ & T2 \\
\hline $200 \mathrm{~g}$ soil $+4 \mathrm{~g}$ biochar $(\mathrm{T} 500-3)(2 \% \mathrm{w} / \mathrm{w})$ & T3 \\
\hline
\end{tabular}

\subsection{Statistical analyses}

The heavy metal adsorption rate was calculated using the following formula:

Heavy metal adsorption rate

$$
(\%)=\frac{c-c_{0}}{c} \times 100 \%,
$$

where $C$ represents the initial heavy metal concentration, and $C_{0}$ represents the concentration after the adsorption experiment.

For the statistical analyses, we performed an ANOVA followed by a least significant difference (LSD) test $(p<0.05)$ to compare the average results of the different treatments (Schabenberger and Gotway, 2017). The figures of the experiment results were generated using SigmaPlot 12.5 and R studio.

\section{Results And Discussion \\ 3.1 Biochar characteristics}


Table 3

The physico-chemical properties of 27 kinds of biochars.

\begin{tabular}{|c|c|c|c|c|c|c|c|c|}
\hline \multirow[t]{2}{*}{ Biochars } & \multirow[t]{2}{*}{$\begin{array}{l}\text { Productive } \\
\text { rate }(\%)\end{array}$} & \multirow[t]{2}{*}{$\begin{array}{l}\text { Ash } \\
(\%)\end{array}$} & \multirow[t]{2}{*}{$\mathrm{pH}$} & \multirow{2}{*}{$\begin{array}{l}\text { EC } \\
(\mathrm{mS} \\
\left.\mathrm{cm}^{-1}\right)\end{array}$} & \multirow[t]{2}{*}{$\begin{array}{l}\text { Carbon } \\
(\%)\end{array}$} & \multicolumn{3}{|c|}{$\begin{array}{l}\text { Acidic surface functional group } \\
\left(\mathrm{mmol} \mathrm{g}^{-1}\right)\end{array}$} \\
\hline & & & & & & Carboxyl & $\begin{array}{l}\text { Weak } \\
\text { acid }\end{array}$ & $\begin{array}{l}\text { Phenolic } \\
\text { hydroxyl }\end{array}$ \\
\hline P300-1 & 50.60 & 8.16 & 6.93 & 0.99 & 30.73 & 1.31 & 0.04 & 1.22 \\
\hline P300-2 & 46.71 & 9.97 & 6.65 & 1.19 & 37.52 & 1.31 & 0.04 & 1.23 \\
\hline P300-3 & 45.63 & 10.00 & 6.43 & 0.64 & 56.89 & 1.33 & 0.03 & 1.25 \\
\hline P400-1 & 37.38 & 7.92 & 6.46 & 0.55 & 46.79 & 1.23 & 0.02 & 1.13 \\
\hline P400-2 & 31.96 & 11.65 & 6.40 & 0.80 & 44.17 & 1.24 & 0.02 & 1.15 \\
\hline P400-3 & 28.39 & 12.38 & 6.85 & 2.07 & 48.90 & 1.22 & 0.03 & 1.14 \\
\hline P500-1 & 36.44 & 13.59 & 6.97 & 2.94 & 47.86 & 1.19 & 0.01 & 1.03 \\
\hline P500-2 & 30.24 & 15.00 & 7.78 & 3.84 & 54.33 & 1.21 & 0.03 & 1.04 \\
\hline P500-3 & 22.82 & 17.65 & 8.93 & 4.32 & 55.35 & 1.23 & 0.02 & 1.08 \\
\hline S300-1 & 64.97 & 29.39 & 7.45 & 15.08 & 30.69 & 1.21 & 0.10 & 1.25 \\
\hline S300-2 & 64.41 & 28.56 & 7.18 & 16.18 & 35.23 & 1.22 & 0.08 & 1.20 \\
\hline S300-3 & 39.29 & 33.58 & 7.56 & 19.30 & 40.66 & 1.22 & 0.10 & 1.22 \\
\hline S400-1 & 50.77 & 37.25 & 8.91 & 20.90 & 33.28 & 1.19 & 0.06 & 1.26 \\
\hline S400-2 & 40.96 & 39.3 & 8.83 & 20.50 & 33.43 & 1.11 & 0.04 & 1.26 \\
\hline S400-3 & 33.96 & 42.10 & 9.46 & 21.00 & 37.04 & 1.10 & 0.07 & 1.18 \\
\hline S500-1 & 43.79 & 46.05 & 10.34 & 23.70 & 34.69 & 1.05 & 0.03 & 1.04 \\
\hline S500-2 & 39.48 & 46.94 & 10.45 & 25.50 & 36.34 & 1.06 & 0.06 & 1.07 \\
\hline S500-3 & 31.62 & 44.36 & 10.24 & 26.40 & 38.54 & 1.07 & 0.03 & 1.08 \\
\hline T300-1 & 65.81 & 9.99 & 7.93 & 3.85 & 47.42 & 1.33 & 0.11 & 1.24 \\
\hline T300-2 & 61.59 & 9.73 & 7.09 & 3.55 & 46.24 & 1.37 & 0.06 & 1.24 \\
\hline Т300-3 & 57.82 & 10.13 & 6.87 & 3.55 & 48.66 & 1.39 & 0.04 & 1.25 \\
\hline T400-1 & 53.52 & 11.84 & 7.42 & 3.83 & 49.53 & 1.19 & 0.03 & 1.11 \\
\hline T400-2 & 52.06 & 12.70 & 7.75 & 3.97 & 53.68 & 1.20 & 0.04 & 1.13 \\
\hline T400-3 & 43.19 & 15.66 & 8.03 & 3.73 & 54.90 & 1.23 & 0.02 & 1.15 \\
\hline
\end{tabular}




\begin{tabular}{|c|c|c|c|c|c|c|c|c|}
\hline \multirow[t]{2}{*}{ Biochars } & \multirow[t]{2}{*}{$\begin{array}{l}\text { Productive } \\
\text { rate }(\%)\end{array}$} & \multirow[t]{2}{*}{$\begin{array}{l}\text { Ash } \\
(\%)\end{array}$} & \multirow[t]{2}{*}{$\mathrm{pH}$} & \multirow{2}{*}{$\begin{array}{l}\text { EC } \\
(\mathrm{mS} \\
\left.\mathrm{cm}^{-1}\right)\end{array}$} & \multirow[t]{2}{*}{$\begin{array}{l}\text { Carbon } \\
(\%)\end{array}$} & \multicolumn{3}{|c|}{$\begin{array}{l}\text { Acidic surface functional group } \\
\left(\mathrm{mmol} \mathrm{g}^{-1}\right)\end{array}$} \\
\hline & & & & & & Carboxyl & $\begin{array}{l}\text { Weak } \\
\text { acid }\end{array}$ & $\begin{array}{l}\text { Phenolic } \\
\text { hydroxyl }\end{array}$ \\
\hline T500-1 & 48.90 & 15.49 & 8.54 & 4.03 & 49.57 & 1.02 & 0.03 & 1.04 \\
\hline T500-2 & 38.98 & 15.92 & 9.29 & 4.18 & 47.09 & 1.02 & 0.02 & 1.02 \\
\hline T500-3 & 38.29 & 16.40 & 9.65 & 5.74 & 51.90 & 1.01 & 0.04 & 1.09 \\
\hline
\end{tabular}

The physico-chemical properties of the biochars are shown in Table 3. The productive rate of biochar showed a tendency to decrease with increasing pyrolysis temperature and time. The biochar productive rates of the three plants $(22.82 \%, 31.62 \%$, and $38.29 \%)$ were the lowest under the condition of $500^{\circ} \mathrm{C}$ and $120 \mathrm{~min}$, which were significantly lower than the rates at the condition of $300^{\circ} \mathrm{C}$ and $30 \mathrm{~min}$. This trend suggests that an increase in pyrolysis temperature and time enhances the rate of decomposition and transformation of cellulose, hemicellulose, lignin, and other components in the plants (Yang et al., 2007; Novak et al., 2009). By comparing the productive rates of biochars produced from different plants under the same production conditions, we found that the productive rate of PB was lower than those of the other two species, which suggests that Phragmites australis was more easily carbonized. This may be due to its spongy like tissue structure and high substrate accessibility as well as the increase in porosity caused by the gradual rise in the production of volatile compounds inside PB particles during the pyrolysis process (Liu et al., 2016; Akar et al., 2018).

The ash content and $\mathrm{pH}$ of biochars increased with increasing pyrolysis temperature and time. Studies have shown that the increasing biochar ash content is due to the increase in mineral residues in biomass with increasing pyrolysis temperature and time (Cao and Harris, 2010; Yuan et al., 2011). As the ash of biochar contains alkaline mineral elements, such as $\mathrm{Na}, \mathrm{Mg}$, and $\mathrm{K}$, the pH showed the same trend as that of the ash content (Usman et al., 2016). Accordingly, the concentration of acidic surface functional groups reduced with increasing pyrolysis temperature and time. The difference in the functional groups of the biochars may be due to the difference in hemicellulose, cellulose, and lignin contents of the different wetland plant species (Cui et al., 2016). Under the same production conditions, the ash content and $\mathrm{pH}$ of SB were significantly higher than those of the other two biochar types, which may be related to the presence of more alkaline substances and higher ash contents in the plants (Raveendran et al., 1995). The EC increased significantly with increasing pyrolysis temperature, and it has been reported that the presence of higher soluble salts in biochar ash could be responsible for higher EC (Zhai et al., 2015).

The carbon percentage of the three types of biochar gradually increased with increasing pyrolysis temperature and time, indicating that the degree of carbonization continued to increase. The carbon contents of PB and TB were higher than that of SB under the same production conditions, which may be due to the higher degree of fibrosis of the two plants (Al-Wabel et al., 2017). The surface of the biochars was rich in many acidic functional groups. The distribution of the three functional groups was similar (Table 3), which may be related to the uniform pyrolysis temperature (Uchimiya et al., 2010). 
As shown in the SEM images (Fig. 1), PB had a typical accordant tubular structure, and its destruction and fragmentation (and thus the specific surface area) notably increased with increasing pyrolysis temperature and time. This finding was the same as the biochar structure derived from lotus stalks, and this configuration may favor the diffusion of heavy metal ions into biochar (Huang et al., 2012). Although the increase in the surface area and pore volume of TB with increasing pyrolysis temperature and time were not as notable as those of $\mathrm{PB}$, the destruction and fragmentation of $\mathrm{TB}$ at $500^{\circ} \mathrm{C}$ strongly affected its pore development (Fig. 1); this could enhance metal ion retention in the soil-biochar environment, despite the generally low specific surface area of TB (Irfan et al., 2016). With a granular or massive structure, the SB maintained a greater specific surface area, and the biochar surface area occurred in the order of $\mathrm{SB}>\mathrm{PB}>\mathrm{TB}$ (Fig. 1).

Table 4

The EDS surface element analysis of three biochars.

\begin{tabular}{|lllll|}
\hline Biochars & $\mathbf{C}(\%)$ & $\mathbf{N}(\%)$ & $\mathbf{O}(\%)$ & $\mathbf{H}(\%)$ \\
\hline P500-3 & 43.51 & 10.23 & 46.26 & ND \\
\hline S500-3 & 58.04 & 6.92 & 35.04 & ND \\
\hline T500-3 & 36.17 & 7.05 & 56.78 & ND \\
\hline ND: not detectable. & & & \\
\hline
\end{tabular}

Biochars produced under the pyrolysis condition of $500^{\circ} \mathrm{C}$ and $120 \mathrm{~min}$ (P500-3, S500-3, and T500-3) were selected as the biochar resource for the incubation experiment because of their higher heavy metal adsorption rate, according to the results of our adsorption experiment. EDS surface element analysis revealed that when the pyrolysis temperature reached $500^{\circ} \mathrm{C}, \mathrm{C}, \mathrm{O}$, and $\mathrm{N}$ became the main elements in the three biochar types, while $\mathrm{H}$ was not detected (detection limit: $0.1 \%$ ) (Table 4). Moreover, the contents of $\mathrm{P}, \mathrm{K}, \mathrm{S}$, and $\mathrm{Mg}$ were close to the detection limit (date not shown). The highest carbon content occurred in the surface of SB $(58.04 \%)$, followed by PB (43.51\%), and the lowest carbon content occurred in TB (36.17\%); this suggests that the percentage of $\mathrm{C}$ on the biochar surface differed to that of the whole biochar. This may be due to the presence of some ash ingredients covering the surface of the biochar (Table 3).

\subsection{Adsorption of $\mathrm{Pb}^{2+} / \mathrm{Cd}^{2+}$ on different biochars in solution}

The results of the adsorption experiment are shown in Fig. 2. In general, the adsorption rate of heavy metal ions by biochars increased with increasing pyrolysis temperature and time in both single and mixed solutions.

In the single solution, the adsorption rate of $\mathrm{Pb}$ and $\mathrm{Cd}$ by $\mathrm{PB}$ increased significantly with increasing pyrolysis temperature and time. Specifically, the adsorption rate of $\mathrm{Pb}$ increased from $39.14 \%$ by P300-1 
to $82.15 \%$ by P500-3, and the adsorption rate of Cd increased from $43.91 \%$ by P300-1 to $84.94 \%$ by $\mathrm{P} 500-3$. The adsorption rate of $\mathrm{Pb}$ by $\mathrm{SB}$ in the single $\mathrm{Pb}^{2+}$ solution stopped increasing significantly when it reached $90 \%$ at the pyrolysis temperature of $400^{\circ} \mathrm{C}$, while the adsorption rate of $\mathrm{Cd}$ by SB in the single $\mathrm{Cd}^{2+}$ solution stopped increasing significantly when it reached $97 \%$ at $500^{\circ} \mathrm{C}$. The adsorption capacity of heavy metal ions per unit mass of biochar is fixed When the adsorption reaches a certain threshold, the removal effect of heavy metal ions by the biochar is weakened (Tan et al., 2015). The adsorption rate of heavy metals by TB showed an increasing trend with increasing pyrolysis temperature, but the trend was not as obvious as that of SB. The maximal adsorption rate of $\mathrm{Pb}$ and $\mathrm{Cd}$ by TB reached $61.74 \%$ and $96.19 \%$ (by T500-3 in single solution). The generally higher adsorption rate in the SB treatment may be related to the higher $\mathrm{pH}$ of SB, as reported by Tan et al. (2015), who found that at higher pH levels, heavy metal cations would outcompete the lower abundance of $\mathrm{H}^{+}$ions in the active sites, which promotes the adsorption of heavy metals into biochar. Further, with increasing $\mathrm{pH}$, the functional group loses a proton and complexes with heavy metals, which increases the adsorption rate (Wang et al., 2009). Moreover, the larger specific surface area of the SB biochar with granular morphology (Fig. 1) and a higher content of weak acidic surface functional groups (Table 3 ) are also the cause for the significantly higher adsorption rates of the two heavy metals by SB than by the other two biochars in the single solution (Cui et al., 2016).

In the mixed solution, the maximum adsorption rate of $\mathrm{Pb}$ and $\mathrm{Cd}$ for each plant biochar pyrolysis time was still $500^{\circ} \mathrm{C}$ (except Cd of P300-2). The heavy metal adsorption rate by the three types of plant biochars mostly decreased by $48.83 \%$ (P400-2), $67.88 \%$ (S400-2), and $35.37 \%$ (T400-3) for Pb; and $62.54 \%$ (P500-3), $65.06 \%$ (S500-1), and $73.6 \%$ (T500-3) for Cd. Compared with the single solutions, the adsorption rate of heavy metals in the mixed solutions decreased significantly, indicating that the coexistence of the two heavy metal ions weakened the adsorption of an individual metal by biochar. This was consistent with a previous finding in which the adsorption of $\mathrm{Zn}$ and $\mathrm{Cu}$ by biochar decreased in the mixed solution relative to that in the single solution, likely because both heavy metal ions occupied the same adsorption sites in the biochar (Chen et al., 2011; Uchimiya et al., 2011). Moreover, both Pb and Cd are divalent metal ions, resulting in competitive adsorption when complexing with a functional group on biochar surfaces (Ma et al., 2016). 
Table 5

Correlations between biochars properties and heavy metals adsorption

\begin{tabular}{|c|c|c|c|c|c|c|c|}
\hline & Ash & $\mathrm{pH}$ & EC & Carbon & $\begin{array}{l}\text { Functional } \\
\text { group }\end{array}$ & $\begin{array}{l}\mathrm{Pb} \\
\text { adsorption }\end{array}$ & $\begin{array}{l}\text { Cd } \\
\text { adsorption }\end{array}$ \\
\hline Ash & 1 & & & & & & \\
\hline $\mathrm{pH}$ & $0.744^{\star \star}$ & 1 & & & & & \\
\hline EC & $0.986^{\star \star}$ & $0.702^{\star \star}$ & 1 & & & & \\
\hline Carbon & $-0.625^{\star \star}$ & -0.226 & $-0.659 * *$ & 1 & & & \\
\hline $\begin{array}{l}\text { Functional } \\
\text { group }\end{array}$ & -0.315 & $-0.649 * *$ & -0.224 & -0.128 & 1 & & \\
\hline $\begin{array}{l}\mathrm{Pb} \\
\text { adsorption }\end{array}$ & $0.837^{\star \star}$ & $0.604 * \star$ & $0.793^{* *}$ & $-0.444^{*}$ & $-0.443^{*}$ & 1 & \\
\hline $\begin{array}{l}\text { Cd } \\
\text { adsorption }\end{array}$ & $0.619 * *$ & $0.876^{\star \star}$ & $0.587 \star \star$ & 0.02 & $-0.571^{\star \star}$ & $0.502^{\star *}$ & 1 \\
\hline
\end{tabular}

The correlation between biochar properties and heavy metal adsorption is shown in Table 5. We observed a significant positive correlation between biochar ash, $\mathrm{pH}$, and $\mathrm{EC}$, which were all negatively correlated with carbon and the concentration of functional groups $(P<0.01)$. The adsorption rate of heavy metals showed a significant positive correlation with biochar ash, $\mathrm{pH}$, and $\mathrm{EC}$ and a significant negative correlation with the number of functional groups $(P<0.01)$. The increase in carbon content significantly inhibited the adsorption of $\mathrm{Pb}(P<0.05)$ and insignificantly promoted the adsorption of $\mathrm{Cd}$.

\subsection{Immobilization of soil $\mathrm{Pb} / \mathrm{Cd}$ after different biochar additions}

The $\mathrm{Pb}$ and $\mathrm{Cd}$ fractions in soils after biochar addition are expressed as percentages of the sum of the individual chemical fractions, and the results are presented in Fig. 3. After 15 days of incubation, the rank order of $\mathrm{Pb}$ fractions in the control group was residual $(80.68 \%)>$ Fe-Mn oxides $(6.49 \%)>$ carbonate $(4.84 \%)>$ exchangeable $(4.10 \%)>$ organic $(3.87 \%)$. The proportion of residual $\mathrm{Pb}$ in each treatment significantly increased after the biochar addition, and the increase in the PB treatments were the highest of the three biochars (by 9.57-12.15\%). The other four $\mathrm{Pb}$ fractions in the treatments were significantly lower than those in the control group. The proportions of exchangeable $\mathrm{Pb}$ in the PB treatments were the lowest, with percentages of $0.95 \%$ in P1, $0.40 \%$ in P2, and $0.08 \%$ in P3 (treatments in Table 2), which is equivalent to a decrease of exchangeable $\mathrm{Pb}$ by $76.82 \%, 97.56 \%$, and $98.00 \%$ compared with the control group (Fig. 3, "15 days $\mathrm{Pb}$ "). According to previous studies, $\mathrm{pH}$ was found to be an important influencing factor on soil heavy metal precipitation, adsorption, and desorption. The addition of high-pH biochars (P500-3:8.93, S500-3:10.24, T500-3:9.65) to the studied soil ( $\mathrm{pH}: 8.13 \pm 0.21)$ may promote an increase in soil pH and surface charge, which would enhance the precipitation of heavy metals (Cao et al., 2009). In 
contrast, the increase of soil pH could promote ion exchange with the biochar surface and reduce the mobility of heavy metals in soils (Adriano et al., 2004). Houben et al. (2013) found that the addition of 10 $\%$ rapeseed biochar had a similar effect to that of lime addition on soil heavy metal fixation, as both mechanisms increased the soil pH. Moreover, the ash of biochars contained alkaline mineral elements. Previous studies have shown that oxygen-containing functional groups and a large number of biochar cations $(\mathrm{Ca}, \mathrm{K})$ are the main cause for the high adsorption efficiency of heavy metals (Ahmad et al., 2014). The addition of carbon-rich biochars (Table 4) would also cause the formation of carbon-centered compounds, which subsequently bind to metals (Huang et al., 2007); this confirms the role of carbon in the reduction of soil exchangeable heavy metals, and, in turn, soil heavy metal mobility and bioavailability (Kumpiene et al., 2008; Al-Wabel et al., 2017). In this study, the conversion of $\mathrm{Pb}$ to the residual state was more strongly promoted by $\mathrm{PB}$ than the other two biochar types. This may be related to the higher content of phosphorus in $\mathrm{PB}$, which combines with $\mathrm{Pb}$ to form $\mathrm{Pb}_{3}\left(\mathrm{PO}_{4}\right)_{2}$ and $\mathrm{Pb}_{5}\left(\mathrm{PO}_{4}\right)_{3} \mathrm{OH}$ precipitates (Cao et al., 2011). These results suggest that biochars derived from different biomasses produced under different conditions and applied at different rates, could generate varying degrees of $\mathrm{Pb}$ immobilization. Hence, the effects of certain biochars are not easily transferable to other biochar sources.

After 30 days of incubation, the distribution of $\mathrm{Pb}$ geochemical fractions under the biochar treatments were similar to those in the control group. This result differs to that after 15 days of incubation. The residual state of the control group was the lowest in all treatments, but not significantly, suggesting that the effect of biochar addition on $\mathrm{Pb}$ immobilization was largely weakened with increasing incubation time. This suggests that the continuous immobilization of $\mathrm{Pb}$ in saline soils via the three wetland plant biochars was limited by time. This result may be due to the high EC value of the soil solution, which leads to active ion exchange (Bäckström et al., 2004), and the available $\mathrm{Pb}$ in the soil solution therefore increased with increasing incubation time.

After 15 days of incubation, $\mathrm{Cd}$ fractions in the control group occurred in the order of residual $(71.97 \%)>$ carbonate $(19.9 \%)>$ organic $(4.37 \%)>$ Fe-Mn oxides $(2.94 \%)>$ exchangeable $(0.79 \%)$. Compared with the control group, the residual state in the biochar addition treatments reduced, while the exchangeable and carbonate states increased significantly, which suggests that the available $\mathrm{Cd}$ in soil increased within 15 days of incubation. Even after 30 days of incubation, the availability of $\mathrm{Cd}$ in soil was higher than in the control group. PB promoted the largest available Cd increase among the three biochars. Similar findings were also observed by previous studies that used other biomaterial-derived biochars. For example, Hou et al. (2011) found that chicken manure and wood chip biochars increased the availability of $\mathrm{Pb}, \mathrm{Cd}$, and $\mathrm{Cu}$ in contaminated soils, which was inferred to be associated with the high residual fraction concentration of these three metals in the studied soil. Moreover, Lin et al. (2007) attributed the increase in soil carbonates and organic-bound heavy metals after bone biochar addition to the higher alkalinity and organic content of biochar. However, conclusive evidence for how biochar promotes the conversion of $\mathrm{Cd}$ from the residue to the available state requires further investigation. Based on previous studies, several possibilities have been proposed: e.g., (1) wetland plant biochars increase the cation exchange capacity, which enhances the adsorption onto the biochar surface (Lehmann et al., 2003); and 
(2) the increase of dissolved organic carbon contained within the biochar could release specific heavy metals (Uchimiya et al., 2012; Xu and Zhao, 2013). Therefore, to some extent, this study found that the addition of biochar increased the mobility and bioavailability of $\mathrm{Cd}$ in the saline soil, despite the lack of conclusive evidence. However, our findings suggest that combining biochar addition and plant-assisted bioremediation (phytoremediation) could efficiently reduce the potential risk of heavy metals in soils.

\subsection{Soil enzyme activities after different biochar additions 3.4.1 Response of soil urease activity to biochar addition}

Three types of biochar were added to wetland soil with different carbon-soil mass ratios, and the effect on soil urease activity is shown in Fig. 4. The addition of different biochars had different effects on soil urease activity, but the difference among the treatment groups of the same plant biochar was not significant. Compared with the control group, the difference in urease in all treatments were not significant, and only the urease activity in the $S 2$ and T3 treatments increased. We compared the differences among the treatment groups of the different plant biochars. For PB, the soil urease activity under the P2 treatment was $17.82 \%$ higher than that under the P1 treatment, and the urease activity in the P3 treatment was $12.02 \%$ lower than that in the P2 treatment. The effect of the different amounts of SB on soil urease activity was the same as that of PB. The soil urease activity of the S2 treatment was $29.57 \%$ higher than that of the S1 treatment, and the urease activity of the S3 treatment was $10.53 \%$ lower than that of the S2 treatment. In the TB treatments, the soil urease activity increased with increasing biochar addition, and the soil urease activity of the T2 and T3 treatments was $1.31 \%$ and 6.52 $\%$ higher than that of the T1 treatment, respectively. When comparing the effects of the different plant biochar treatments on soil urease activity, we found that under low and high biochar additions, the soil urease activity of TB was higher than that of PB and SB; under medium biochar addition, the soil urease activity was not significantly different.

In this study, the effect of biochar on soil urease activity was first promoted and then inhibited with increase in addition. As previously mentioned, the causes for the effect of biochar on soil urease activity are complicated. Combined with the results of this study, we suggest that the low addition of biochar facilitates the formation of soil aggregates, improves the aeration and water retention capacity of soil, and enhances the growth and reproduction of soil microorganisms (Hamer et al., 2004). Moreover, the addition of biochar increases the content of soil organic matter, which not only benefits the growth and utilization of microorganisms but also provides raw materials (Glaser et al., 2002) for urease reactions. In addition, the adsorption of urease substrates by biochar also promotes enzymatic reactions (Zhou Zhenfeng et al., 2015). When the amount of biochar increases, excessive biochar adsorption protects the binding site for enzymatic reactions and inhibits their progress (Lehmann and Joseph, 2015).

\subsubsection{Response of soil sucrase activity to biochar addition}

Three types of biochar were added to wetland soil at different carbon-soil mass ratios, and the effect on soil sucrase activity is shown in Fig. 5 . Compared with the control group, except for the P1 treatment, the 
soil sucrase activity in the other biochar addition treatments was significantly higher than that in the control group, indicating that the addition of biochar promoted soil sucrase activity. Compared with the differences in the same plant biochar treatment group, it was found that soil sucrase activity generally increased with increasing biochar addition. For the PB group, soil sucrase activity in the P2 and P3 treatments increased by $53.34 \%$ and $75.08 \%$, respectively, compared with the P1 treatment; in the SB treatment, we observed no significant difference in sucrase activity between the S2 treatment and the S1 treatment, and sucrase activity in the S3 treatment was $23.55 \%$ higher than that in S1 treatment; in the TB treatment, the T2 and T3 treatments increased sucrase activity by $10.37 \%$ and $15.36 \%$ compared with that of the T1 treatment. Our results showed that the sucrase activity of SB and TB was significantly higher than that of PB in the low addition treatment; however the sucrase activity of the PB treatment was higher than that of SB and TB in the high addition treatment, but the difference was not significant.

The soil sucrase activity increased with increasing biochar addition, which suggests that biochar addition improved the soil environment, enhanced the growing conditions for microorganisms, and increased the number of microorganisms in the soil. Moreover, biochar addition promoted the hydrolysis of sugars in soil, accelerated the cycling of carbon in soil, and promoted the enzymatic reaction related to sucrase, thus improving soil nutrient availability (Chen et al., 2017a; Glaser et al., 2002).

\subsubsection{Response of soil catalase activity to biochar addition}

Three types of biochar were added to wetland soil with different carbon-soil mass ratios, and the effect on soil catalase activity is shown in Fig. 6. Compared with the control group, the PB treatment increased the soil catalase activity, while in the SB biochar treatment, soil catalase activity increased in the S1 and S2 treatments but decreased in the S3 treatment. Moreover, the addition of TB decreased soil catalase activity, which suggests that different plant biochars had different effects on soil catalase activity. PB addition and the medium and low addition of SB promoted soil catalase activity, while TB addition and the high addition of SB inhibited soil catalase activity. By comparing the differences among the treatments with the same plant biochar addition, we found that soil catalase activity first increased and then decreased in the PB treatment. Compared with the P1 treatment, soil catalase activity of the P2 treatment increased by $7.92 \%$. Moreover, the soil catalase activity of the P3 treatment was $6.53 \%$ and 13.39 \% lower than that of the P1 and P2 treatments, respectively. The change trend of the soil catalase activity in the S2 treatment was similar in both the SB and PB treatments. The S2 treatment increased the soil catalase activity by $4.62 \%$ compared with the S1 treatment. S3 treatment decreased by $32.48 \%$ and $35.47 \%$ compared with the S1 and S2 treatments, respectively. In the TB treatment, the soil catalase activity increased with increasing biochar addition, and the enzyme activity of the T2 and T3 treatments increased by $43.91 \%$ and $75.64 \%$ compared with the $\mathrm{T} 1$ treatment, respectively. By comparing the catalase activity of the different plant biochar treatments under the same biochar addition, we found no significant difference in the catalase activity between the PB and SB treatments under low and medium biochar additions; however, their values were significantly higher than those in the TB biochar treatment, and the soil catalase activity under high biochar addition occurred in the order of P3 $>$ S3 $>$ T3. 
Compared with the control group, the addition of PB and SB increased the soil catalase activity, while the addition of TB decreased the catalase activity. A previous study found that $0.5 \%$ corn straw charcoal inhibited catalase activity in brown loam soil, which was attributed to the higher $\mathrm{pH}$ of biochar. However, this cause does not apply to the results of this study (Feng Aiqing et al., 2015). Based on the properties of the biochar itself, we speculate that PB and SB may have a higher lignin content than TB, which more easily adsorbs to the binding sites of enzyme molecules in the enzymatic reaction of catalase, and thus inhibits this reaction. Increasing TB addition was found to increase the adsorption of substrates during the enzymatic reaction, which significantly increased the soil catalase activity due to enhanced enzymatic reactions (Zhou Zhenfeng et al., 2015).

\subsubsection{ANOVA of biochar addition and soil enzyme activity}

Table 6

Two-Way ANOVA (Plants and addition) for all three enzyme activities studied of a wetland soil

\begin{tabular}{|lllllll|}
\hline Biochars & \multicolumn{2}{l}{ Urease activity } & \multicolumn{2}{l|}{ Sucrase activity } & \multicolumn{2}{l|}{ Catalase activity } \\
\cline { 2 - 7 } & $\boldsymbol{F}$ & $\boldsymbol{p}$ & $\boldsymbol{F}$ & $\boldsymbol{p}$ & $\boldsymbol{F}$ & $\boldsymbol{p}$ \\
\hline Plants & 2.969 & 0.077 & 0.397 & 0.678 & 54.491 & $<\mathbf{0 . 0 0 1}$ \\
\hline Addition & 2.776 & 0.089 & 16.262 & $<0.001$ & 3.402 & 0.056 \\
\hline Plants*Addition & 0.851 & 0.512 & 3.656 & $0.024^{\star}$ & 5.839 & $\mathbf{0 . 0 0 3}$ \\
\hline
\end{tabular}

The plant species and amount of biochar had a significant effect on typical soil enzyme activity. Table 6 shows the results of the two-way ANOVA of multiple dependent variables. Through the analysis of the effects and causes of different biochars on the activities of three typical enzymes, we found that the mechanism and causes for the effect of biochar are complicated. Table 6 shows that the biochar plant type had a significant effect on soil catalase activity, which suggests that biochar from different biomass sources had significantly different effects on soil catalase activity. In contrast, their effects on urease and sucrase was not significantly different. The addition of biochar had a significant effect on soil sucrase activity, but no significant effect on urease and catalase activity. The interaction between the type and amount of biochar only induced a significant difference in soil catalase activity $(p<0.05)$. The results showed that different plant biochars and different amounts of biochars had an interactive effect on the change of soil sucrase and catalase activity.

\section{Conclusions}

Biomass types, pyrolysis temperature, and pyrolysis time had significant effects on the physico-chemical properties of biochar. Higher temperatures and longer pyrolysis times increased the carbonization degree of biomass, ash content, and alkalinity. PB had the lowest production rate, highest carbon content, and the most obvious pore structure. SB had the highest $\mathrm{pH}, \mathrm{EC}$, and specific surface area. 
Biochar significantly adsorbed heavy metals in solution, and a higher adsorption effect of biochar was accompanied by a higher degree of carbonization. The adsorption effect of $\mathrm{Pb}$ and $\mathrm{Cd}$ by SB was the most significant in the single solution. Moreover, adsorption competition between the two heavy metals occurred in the mixed solution, and $\mathrm{Cd}$ adsorption was more inhibited than that of $\mathrm{Pb}$.

The PB and SB had short-term fixation to exchangeable $\mathrm{Pb}$ in soil. Biochar addition first fixed and then released exchangeable $\mathrm{Pb}$ in the soil. In contrast, biochar addition promoted the conversion of $\mathrm{Cd}$ from the residue to the less immobile fractions. Therefore, it is necessary to select the appropriate biochars for the remediation of heavy metal pollution in wetland soils.

The addition of biochar significantly increased soil sucrase activity. The effect on soil urease activity was not significant, but low amounts of biochar could promote soil urease activity to a certain extent. Soil urease activity was also inhibited with increasing amounts of biochar. PB and SB significantly promoted the catalase activity compared with control treatment, while TB significantly inhibited the soil catalase activity. Due to the complexity of biochar structures, soil enzyme activities, and the enzyme molecule itself, different biochars had different effects on the same enzyme activity, and the same biochar had different effects on different enzyme activities. The specific mode of action and mechanisms therefore need to be further explored in future investigations.

\section{Declarations}

\section{Funding}

This study was financially supported by the China Postdoctoral Science Foundation (2020M671924). The authors gratefully acknowledge lab members Chen Wang, Xinyan Wang,Yuan Cui and the anonymous reviewers for their great helps and valuable suggestions.

\section{Author information}

Lidi Zheng\&Chuan Tong: School of Geographical Sciences, Fujian Normal University.

Jujuan Gao: Fujian Minjiang River Estuary Wetland National Nature Reserve Adminitrative Office.

Rong Xiao: College of Environment and Resources, Fuzhou University.

\section{Contributions}

LZ and RX designed, analyzed, and wrote the manuscript; CT and JG performed the experiments; LZ provided the funding. All authors read and approved the final manuscript.

\section{Corresponding author}

Correspondence to Rong Xiao: xiaorong_526@163.com 


\section{Ethics approval and consent to participate}

Not applicable.

\section{Consent for publication}

Not applicable.

\section{Data availability}

The datasets used and/or analyzed during the current study are available from the corresponding author on reasonable request.

\section{Competing interests}

The authors declare that they have no competing interests.

\section{References}

1. Adriano DC, Wenzel WW, Vangronsveld J, Bolan NS (2004) Role of assisted natural remediation in environmental cleanup. Geoderma 122:121-142

2. Ahmad M, Rajapaksha AU, Lim JE, Zhang M, Bolan N, Mohan D, Vithanage M, Lee SS, Ok YS (2014) Biochar as a sorbent for contaminant management in soil and water: a review. Chemosphere 99:1933

3. Akar T, Uzun C, Çelik S, Akar ST (2018) Biosorption of Basic Blue 7 by fungal cells immobilized on the green-type biomatrix of Phragmites australis spongy tissue. International Journal of Phytoremediation 20(2):145-152

4. Al-Wabel MI, Usman ARA, Al-Farraj AS, Ok YS, Abduljabbar A, Al-Faraj Al, Sallam AS (2017) Date palm waste biochars alter a soil respiration, microbial biomass carbon, and heavy metal mobility in contaminated mined soil. Environ. Geochem. Health, 1-18

5. Bäckström M, Karlsson S, Bäckman L, Folkeson L, Lind B (2004) Mobilisation of heavy metals by deicing salts in a roadside environment. Water Res 38:720-732

6. Beesley L, Moreno-Jiménez E, Gomez-Eyles JL (2010) Effects of biochar and greenwaste compost amendments on mobility, bioavailability and toxicity of inorganic and organic contaminants in a multi-element polluted soil. Environ Pollut 158:2282-2287

7. Bian RJ, Joseph S, Cui LQ, Pan GX, Li LQ, Liu XY, Zhang AF, Rutlidge H, Wong S, Chia C, Marjo C, Gong B, Munroe P, Donne S (2014) A three-year experiment confirms continuous immobilization of cadmium and lead in contaminated paddy field with biochar amendment. J Hazard Mater 272:121128

8. Cao X, Ma L, Gao B, Harris W (2009) Dairy manure-derived biochar effectively sorbs lead and atrazine. Environ Sci Technol 43:3285-3291 
9. Cao X, Ma L, Liang Y, Gao B, Harris W (2011) Simultaneous immobilization of lead and atrazine in contaminated soils using dairy-manure biochar. Environ Sci Technol 45:4884-4889

10. Cao XD, Harris W (2010) Properties of dairy manure-derived biochar pertinent to its potential use in remediation. Bioresour Technol 101:5222-5228

11. Celis R, Hermosin MC, Cornejo J (2000) Heavy metal adsorption by functionalized clays. Environ Sci Technol 34:4593-4599

12. Chen XC, Chen GC, Chen LG, Chen YX, Lehmann J, McBride MB, Hay AG (2011) Adsorption of copper and zinc by biochars produced from pyrolysis of hardwood and corn straw in aqueous solution. Bioresour Technol 102:8877-8884

13. Cheng QL, Lou GY, Huang WH, Li XD (2017) Assessment and potential sources of metals in the surface sediments of the Yellow River Delta, Eastern China. Environ. Sci. Pollut. R., 1-9

14. Cui XQ, Hao HL, Zhang CK, He ZL, Yang XE (2016) Capacity and mechanisms of ammonium and cadmium sorption on different wetland-plant derived biochars. Sci Total Environ 539:566-575

15. Dai J, Liu YS (2013) Adsorption of $\mathrm{Pb}^{2+}$ and $\mathrm{Cd}^{2+}$ onto biochars derived from pyrolysis of four kinds of biomasses. Acta Sci Nat Univ Pekin 49:1075-1082

16. Edwards JH, Wood CW, Thurlow DL, Ruf ME (1992) Tillage and crop rotation effects on fertility status of a hapludult soil. Soil Sci Soc Am J 56(5):1577-1582

17. Feng AQ, Zhang M, Li CL, Yang YC, Chen BC (2015) Effects of straw and straw biochar on wheat nutrient uptake and enzyme activity in brown soil. Acta Ecol Sin 35(15):5269-5277

18. Gianfreda L, Rao MA (2008) Interactions between xenobiotics and microbial and enzymatic soil activity. Critical Reviews in Environmental Science Technology 38(4):269-310

19. Hou YW, Zeng YF, An ZL (2011) Effect of the application of biochar on the chemical fraction of heavy metals in polluted red soil. Journal of Inner Mongolia University (Natural Science Edition) 42:460466

20. Houben D, Evrard L, Sonnet P (2013) Beneficial effects of biochar application to contaminated soils on the bioavailability of $\mathrm{Cd}, \mathrm{Pb}$ and $\mathrm{Zn}$ and the biomass production of rapeseed (Brassica napus $\mathrm{L}$.). Biomass Bioenerg 57:196-204

21. Hu YL, Wang SL, Zeng DH (2006) Effects of single chinese fir and mixed leaf litters on soil chemical, microbial properties and soil enzyme activities. Plant Soil 282(1-2):379-386

22. Huang D, Liu L, Zeng G, Xu P, Huang C, Deng L, Wang R, Wan J (2017) The effects of rice straw biochar on indigenous microbial community and enzymes activity in heavy metal-contaminated sediment. Chemosphere 174:545-553

23. Huang JM, Huang RQ, Jiao JJ, Chen KP (2007) Speciation and mobility of heavy metals in mud in coastal reclamation areas in Shenzhen, China. Environ Geol 53:221-228

24. Huang LH, Sun YY, Yue QK, Yue QY, Li L, Gao BY (2012) Adsorption of Cd (II) on lotus stalks-derived activated carbon: batch and column studies. Desalin Water Treat 41:122-130 
25. Igalavithana AD, Lee SE, Lee YH, Tsang DC, Rinklebe J, Kwon EE, Ok YS (2017) Heavy metal immobilization and microbial community abundance by vegetable waste and pine cone biochar of agricultural soils. Chemosphere 174:593-603

26. Imparato V, Hansen V, Santos SS, Nielsen TK, Giagnoni L, Hauggaard-Nielsen H, Johansen A, Renella G, Winding A (2016) Gasification biochar has limited effects on functional and structural diversity of soil microbial communities in a temperate agroecosystem. Soil Biol Biochem 99:128-136

27. Irfan M, Lin QM, Yue Y, Ruan X, Chen Q, Zhao XR, Dong XL (2016) Co-production of biochar, bio-oil, and syngas from Tamarix chinensis biomass under three different pyrolysis temperatures. BioResources 11:8929-8940

28. Kumpiene J, Lagerkvist A, Maurice $\mathrm{C}$ (2008) Stabilization of $\mathrm{As}, \mathrm{Cr}, \mathrm{Cu}, \mathrm{Pb}$ and $\mathrm{Zn}$ in soil using amendments-a review. Waste Manage 28:215-225

29. Lehmann J, Da Silva JP, Steiner C, Nehls T, Zech W, Glaser B (2003) Nutrient availability and leaching in an archaeological Anthrosol and a Ferralsol of the Central Amazon basin: fertilizer, manure and charcoal amendments. Plant Soil 249:343-357

30. Lehmann J, Rillig MC, Thies J, Masiello CA, Hockaday WC, Crowley D (2011) Biochar effects on soil biota-a review. Soil Biol Biochem 43(9):1812-1836

31. Lin AJ, Zhang XH, Su YH, Hu Y, Cao Q, Zhu YG (2007) Chemical fixation of metals in soil using bone char and assessment of the soil genotoxicity. Environmental science 28:232-237

32. Liu P, Yue M, Zhang HY (2016) Adsorptive performance of Ni (II) from aqueous solutions using biochar made of Phragmites australis by adding ammonium polyphosphate as flame retardant. Journal of Chemistry. 2016, 1-6

33. Liu ZG, Zhang F-S (2009) Removal of lead from water using biochars prepared from hydrothermal liquefaction of biomass. J Hazard Mater 167:933-939

34. Ma F, Zhao B, Diao J (2016) Adsorption of cadmium by biochar produced from pyrolysis of corn stalk in aqueous solution. Water Sci Technol 74(6):1335-1345

35. Mukherjee A, Zimmerman AR, Harris W (2011) Surface chemistry variations among a series of laboratory-produced biochars. Geoderma 163:247-255

36. Novak JM, Lima I, Xing BS, Gaskin JW, Steiner C, Das KC, Ahmedna M, Rehrah D, Watts DW, Busscher WJ (2009) Characterization of designer biochar produced at different temperatures and their effects on a loamy sand. Annals of Environmental Science 3:195-206

37. Park JH, Choppala GK, Bolan NS, Chung JW, Chuasavathi T (2011) Biochar reduces the bioavailability and phytotoxicity of heavy metals. Plant Soil 348:439

38. Paz-Ferreiro J, Gascó G, Gutiérrez B, Méndez A (2012) Soil biochemical activities and the geometric mean of enzyme activities after application of sewage sludge and sewage sludge biochar to soil. Biol Fertil Soils 48(5):511-517

39. Raveendran K, Ganesh A, Khilar KC (1995) Influence of mineral matter on biomass pyrolysis characteristics. Fuel 74:1812-1822 
40. Rinklebe J, Shaheen SM, Frohne T (2016) Amendment of biochar reduces the release of toxic elements under dynamic redox conditions in a contaminated floodplain soil. Chemosphere 142:4147

41. Schabenberger O, Gotway CA (2017) Statistical methods for spatial data analysis. CRC press

42. Schimmelpfennig S, Glaser B (2012) One step forward toward characterization: some important material properties to distinguish biochars. J Environ Qual 41:1001-1013

43. Shen X, Huang DY, Ren XF, Zhu HH, Wang S, Xu C, He YB, Luo ZC, Zhu QH (2016) Phytoavailability of $\mathrm{Cd}$ and $\mathrm{Pb}$ in crop straw biochar-amended soil is related to the heavy metal content of both biochar and soil. J Environ Manage 168:245-251

44. Sohi SP, Krull E, Lopez-Capel E, Bol R (2010) A review of biochar and its use and function in soil, Advances in agronomy. Elsevier, pp 47-82

45. Sopeña F, Bending GD (2013) Impacts of biochar on bioavailability of the fungicide azoxystrobin: a comparison of the effect on biodegradation rate and toxicity to the fungal community. Chemosphere 91(11):1525-1533

46. Tan XF, Liu YG, Zeng GM, Wang X, Hu XJ, Gu YL, Yang ZZ (2015) Application of biochar for the removal of pollutants from aqueous solutions. Chemosphere 125:70-85

47. Tessier A, Campbell PGC, Bisson M (1979) Sequential extraction procedure for the speciation of particulate trace metals. Anal Chem 51:844-851

48. Tong XJ, Li JY, Yuan JH, Xu RK (2011) Adsorption of Cu (II) by biochars generated from three crop straws. Chem Eng J 172:828-834

49. Uchimiya M, Cantrell KB, Hunt PG, Novak JM, Chang S (2012) Retention of heavy metals in a typic kandiudult amended with different manure-based biochars. J Environ Qual 41:1138-1149

50. Uchimiya M, Chang S, Klasson KT (2011) Screening biochars for heavy metal retention in soil: role of oxygen functional groups. J Hazard Mater 190:432-441

51. Uchimiya M, Lima IM, Klasson T, Chang K, Wartelle S, Rodgers LH, J. E (2010) Immobilization of heavy metal ions (Cull, CdII, Nill, and PbII) by broiler litter-derived biochars in water and soil. J Agric Food Chem 58:5538-5544

52. Usman ARA, Al-Wabel MI, Abdulaziz A-H, Mahmoud W-A, EL-NAGGAR AH, Abdulelah AHMAD,M, Abdulrasoul A-F, A.-O (2016) Conocarpus biochar induces changes in soil nutrient availability and tomato growth under saline irrigation. Pedosphere 26:27-38

53. Wang JJ, Bai JH, Zhao QQ, Lu QQ, Xia ZJ (2016) Five-year changes in soil organic carbon and total nitrogen in coastal wetlands affected by flow-sediment regulation in a Chinese delta. Sci Rep. https://doi.org/10.1038/srep21137

54. Wang Y, Tang XW, Chen YM, Zhan LT, Li ZZ, Tang Q (2009) Adsorption behavior and mechanism of Cd (II) on loess soil from China. J Hazard Mater 172:30-37

55. Xu RK, Zhao AZ (2013) Effect of biochars on adsorption of Cu (II), Pb (II) and Cd (II) by three variable charge soils from southern China. Environ Sci Pollut R 20:8491-8501 
56. Yang HP, Yan R, Chen HP, Lee DH, Zheng CG (2007) Characteristics of hemicellulose, cellulose and lignin pyrolysis. Fuel 86:1781-1788

57. Yao XY, Xiao R, Ma ZW, Xie Y, Zhang MX, Yu FH (2016) Distribution and contamination assessment of heavy metals in soils from tidal flat, oil exploitation zone and restored wetland in the Yellow River Estuary. Wetlands 36:153-165

58. Yin DX, Wang X, Chen C, Peng B, Tan CY, Li HL (2016) Varying effect of biochar on Cd, Pb and As mobility in a multi-metal contaminated paddy soil. Chemosphere 152:196-206

59. Yuan HR, Lu T, Zhao D, Huang HY, Noriyuki K, Chen Y (2013) Influence of temperature on product distribution and biochar properties by municipal sludge pyrolysis. J Mater Cycles Waste Manage 15:357-361

60. Yuan JH, Xu RK, Wang N, Li JY (2011) Amendment of acid soils with crop residues and biochars. Pedosphere 21:302-308

61. Zhai LM, CaiJi ZM, Liu J, Wang HY, Ren TZ, Gai XP, Xi B, Liu HB (2015) Short-term effects of maize residue biochar on phosphorus availability in two soils with different phosphorus sorption capacities. Biol Fertility Soils 51:113-122

62. Zhang C, Nie S, Liang J, Zeng GM, Wu HP, Hua SS, Liu JY, Yuan YJ, Xiao HB, Deng LJ (2016) Effects of heavy metals and soil physicochemical properties on wetland soil microbial biomass and bacterial community structure. Sci Total Environ 557:785-790

63. Zhang ZH, Solaiman ZM, Meney K, Murphy DV, Rengel Z (2013) Biochars immobilize soil cadmium, but do not improve growth of emergent wetland species Juncus subsecundus in cadmiumcontaminated soil. J Soils Sed 13:140-151

64. Zheng LD, Zhang MX, Xiao R, Chen JX, Yu FH (2017) Impact of salinity and Pb on enzyme activities of a saline soil from the Yellow River delta: A microcosm study, 97. Physics and Chemistry of the Earth, Parts A/B/C, pp 77-87

65. Zhou ZF, Wang JC, Rao XX (2015) Impact of Adding Biochar on Enzyme Activity in Soil. Acta Agriculturae Jiangxi

\section{Figures}



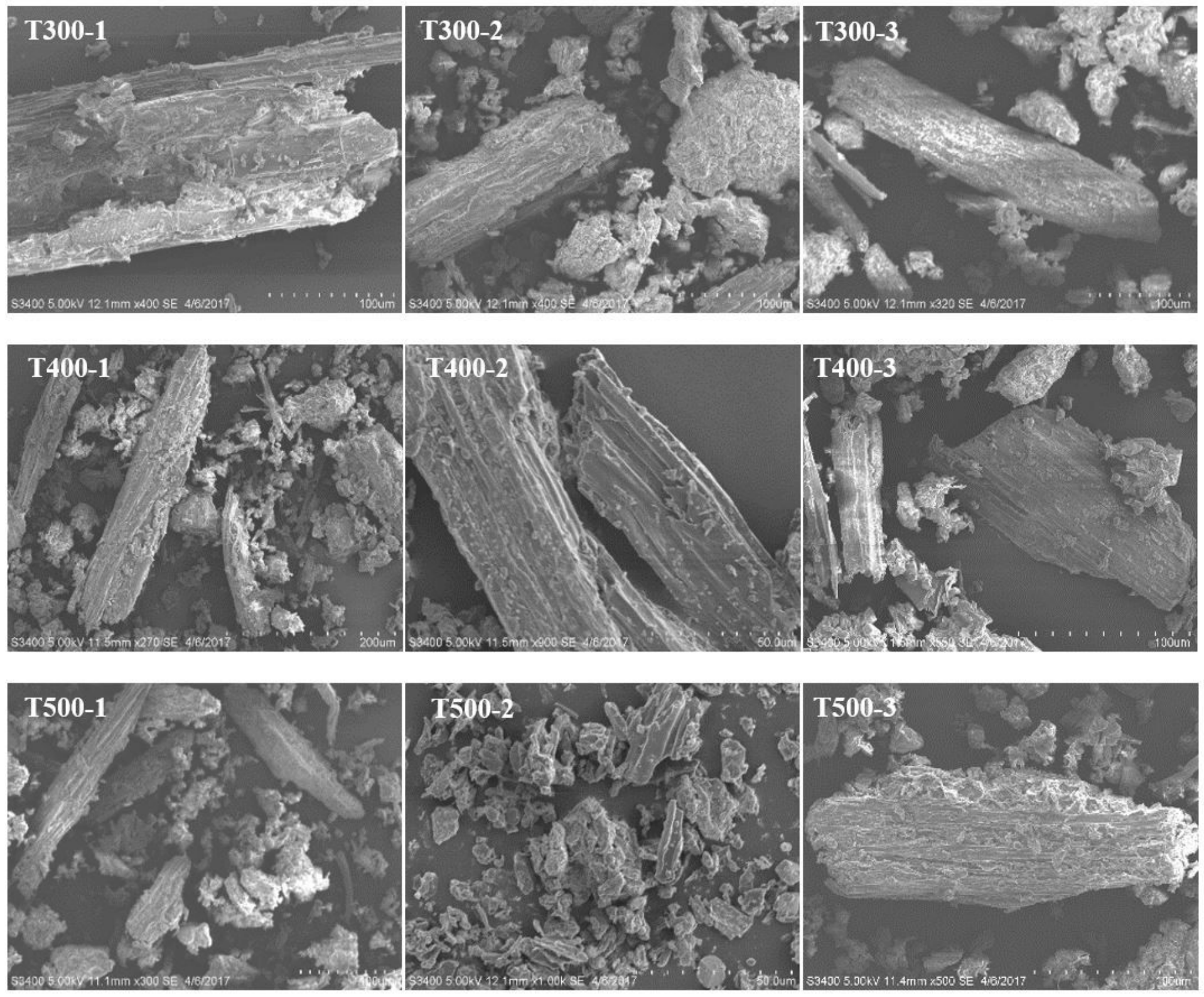

\section{Figure 1}

The SEM image of 27 kinds of biochars. 

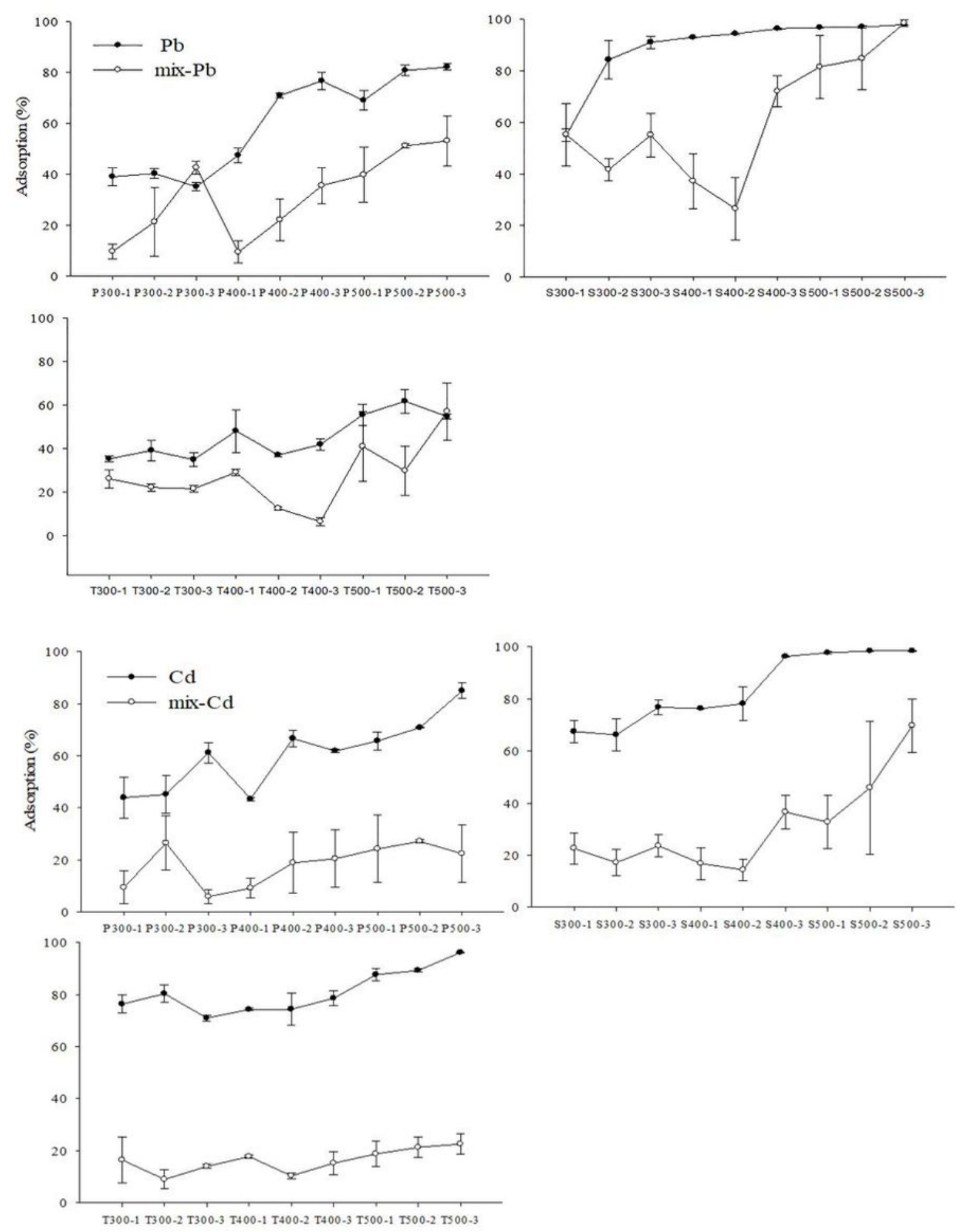

\section{Figure 2}

$\mathrm{Pb}$ and $\mathrm{Cd}$ adsorption by different biochars in single and mixed solutions. Except for the individual treatment, the adsorption rate of heavy metals in the mixed solution was lower than that of the single solution; the metal adsorption rate increased with increasing degree of carbonization; the adsorption rate of the two heavy metals by SB was more significant than by the other two biochars. 

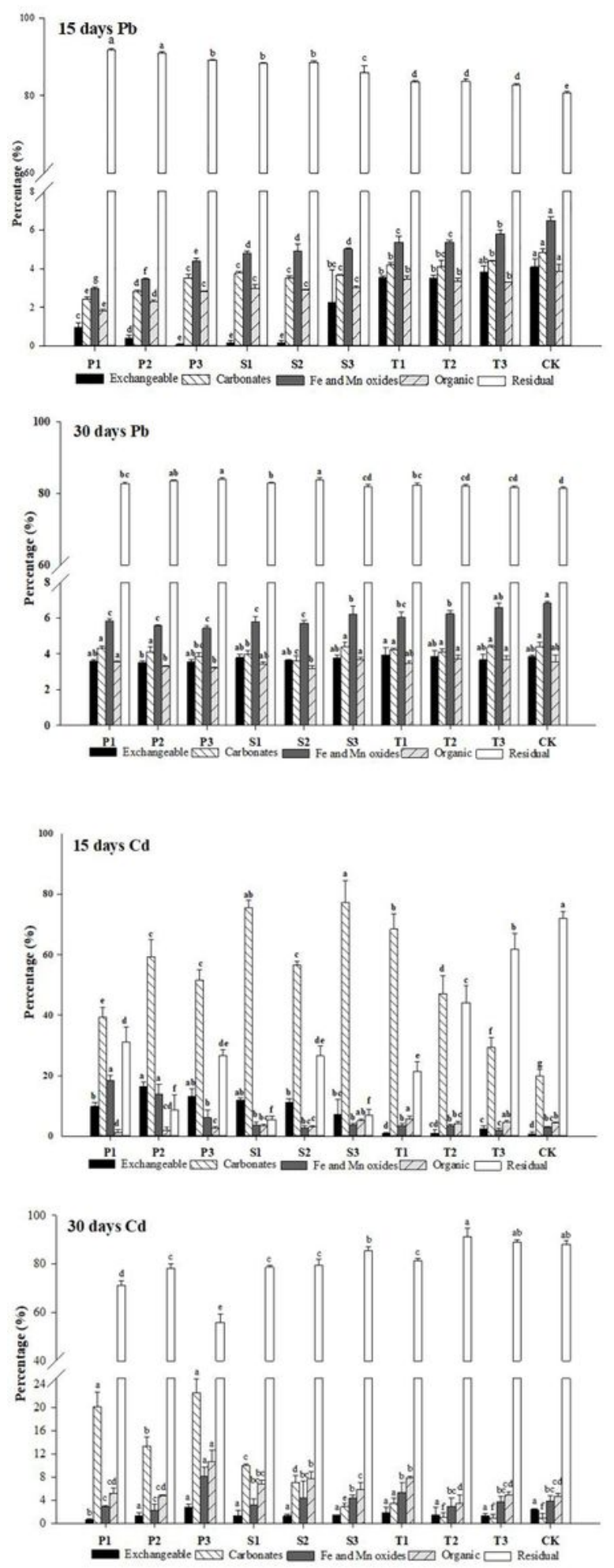

Figure 3

Geochemical fractions of $\mathrm{Pb}$ and $\mathrm{Cd}$ after biochar addition on the 15th and 30th day of incubation (mean percentage $+S E)$. The different letters represent significant differences $(P<0.05)$ in the same geochemical fraction between different biochar additions. 


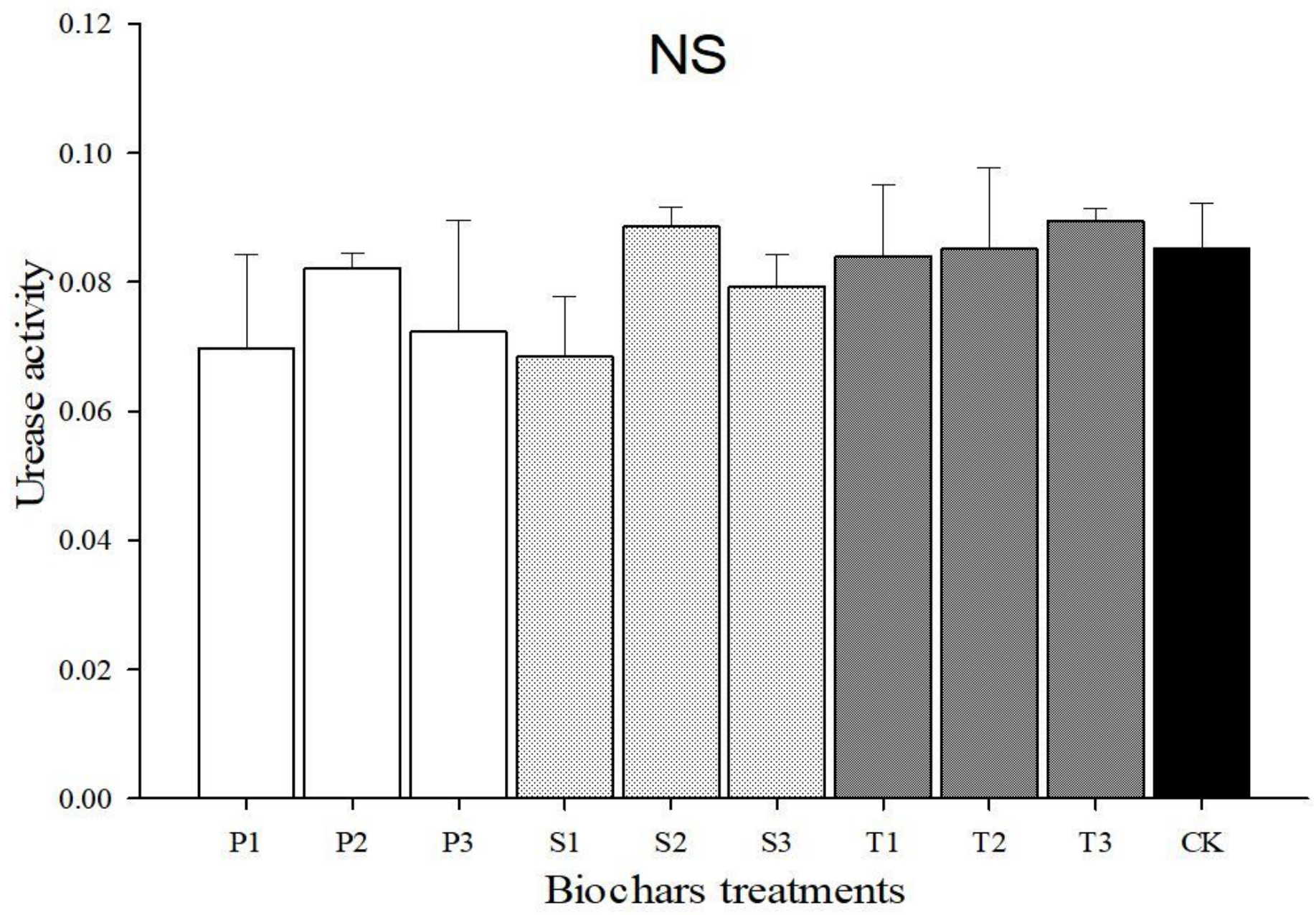

Figure 4

Effect of different biochars with different additions on soil urease activity (NS:no significantly) 


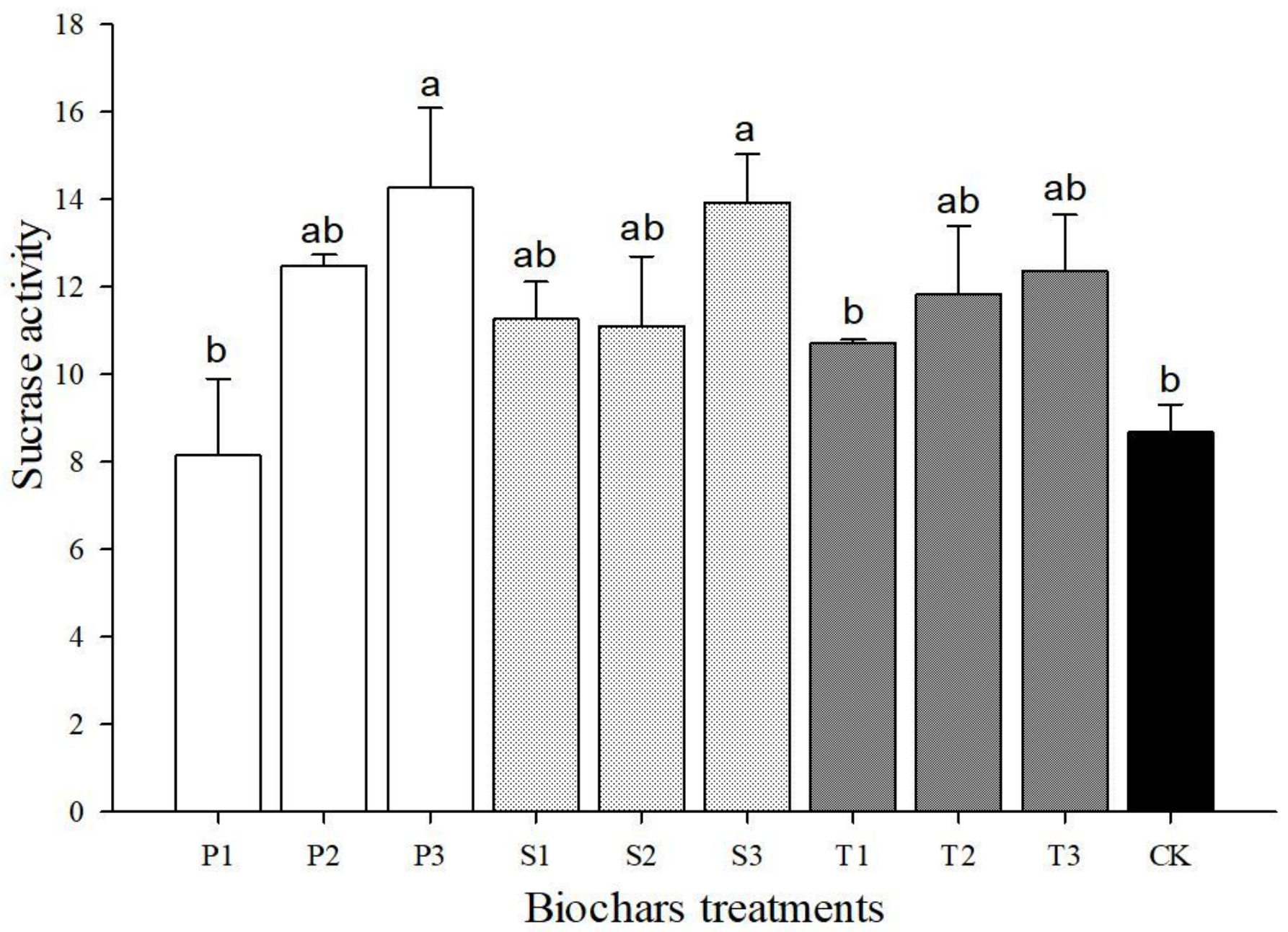

Figure 5

Effect of different biochars with different additions on soil sucrase activity 


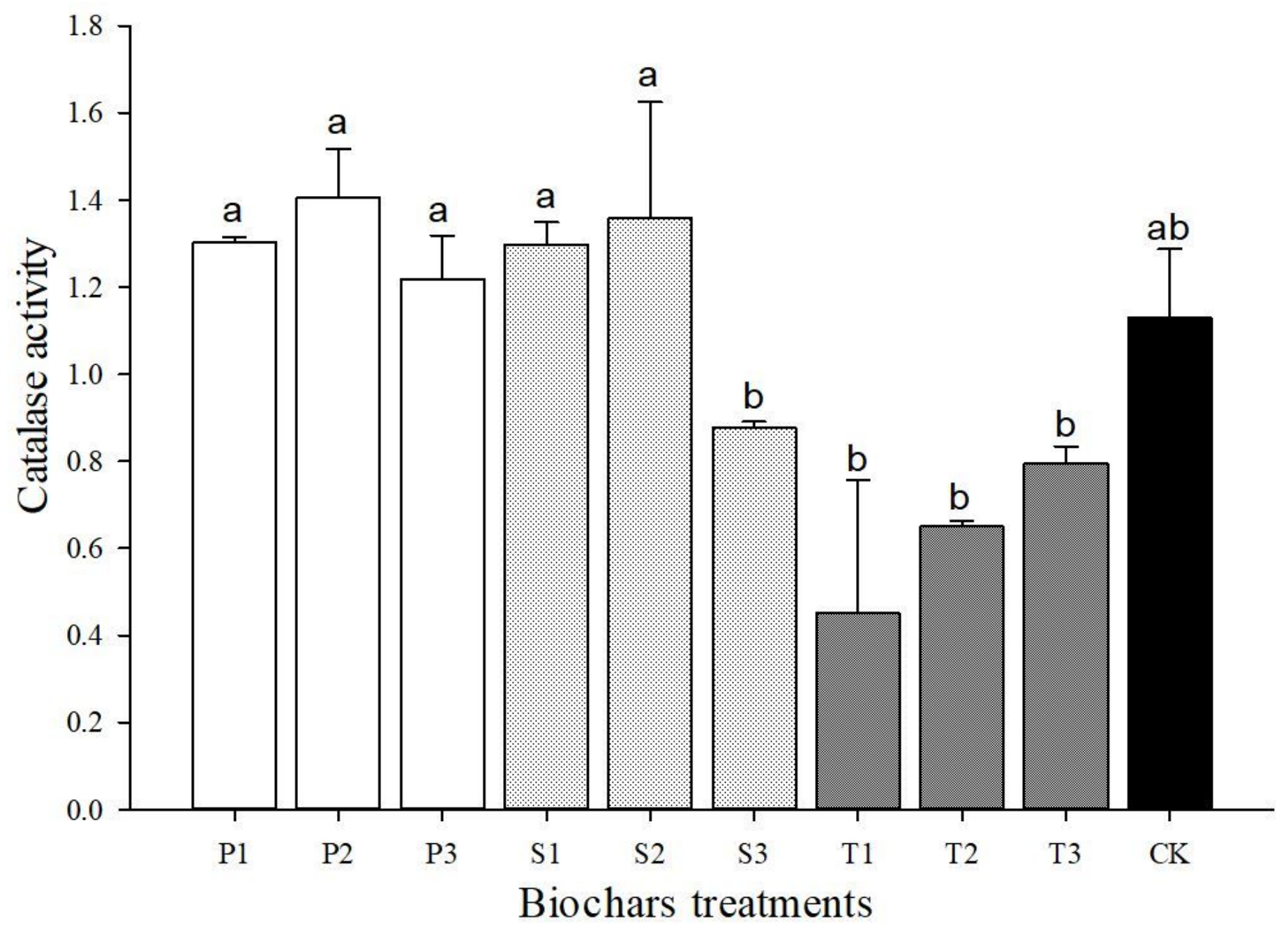

Figure 6

Effect of different biochars with different additions on soil catalase activity. 